\title{
Prevalence of Lip and Tongue Squamous Cell Carcinoma (Scc) at a Pathological Anatomy Service in Northeast Brazil
}

\author{
Prevalencia del Carcinoma de Celulas Escamosas en Labios y Lengua \\ (SCC) en un Servicio de Anatomía Patológica en el Noreste Brasil
}

\begin{abstract}
Rebeca Sá Leitão de Sousa Freitas; Acsa Carlos Maia1; Rodrigo Rodrigues Rodrigues²; Larissa Santos Amaral Rolim²; Lélia Batista de Souza² \& Pedro Paulo de Andrade Santos ${ }^{3}$
\end{abstract}

FREITAS, R. S. L. S.; MAIA, A. C.; RODRIGUES, R. R.; ROLIM, L. S. A.; SOUZA, L. B. \& ANDRADE SANTOS, P. P. Prevalence of lip and tongue squamous cell carcinoma (SCC) at a pathological anatomy service in Northeast Brazil. Int. J. Odontostomat., 15(2):409-414, 2021.

\begin{abstract}
The aim of this work was to trace an epidemiological and clinical profile of oral squamous cell carcinoma (SCC) cases diagnosed as lip and tongue SCC from June 2001 to 2018 at a pathology anatomy service located in Northeastern Brazil. Age, sex, duration, location, growth type, staining, metastasis, etiologic agents and lesion size data were obtained from patient clinical files and histopathological reports. A total of 124 cases were recorded, with tongue SCC being the most prevalent. The common characteristics of both assessed SCCs included higher frequency in men, mean age of 60 years old, evidence mostly of exophytic lesions and maximum size of $4 \mathrm{~cm}$, predominantly diagnosed after a maximum of 1 year of appearance. Regarding divergent findings, lip SCC occurred mostly in the lower portion of the lip, presenting a predominantly leukoplastic color, with regular smoking habits and sunlight identified as the main etiological agents, and no strong relation to metastasis. On the other hand, tongue SCC mostly exhibiting predominantly erythroleukoplastic staining, with a greater relationship to alcoholassociated smoking and regular smoking habits. The highest percentage of patients with metastasis presented tongue SCC. Although lip and tongue SCC display a male preference, an increasing amount of female involvement has been noted over the years, due to the adoption of deleterious habits such as smoking and alcoholism. Tongue SCC presented a greater relationship with metastasis and clinical leukoeritroplastic evidence. This greater aggressiveness could be related to the unfavorable location of these lesions in relation to lip SCC, sometimes making it difficult to identify in their early development stages.
\end{abstract}

KEY WORDS: Lip cancer, tongue cancer, squamous cells cancer, alcoholism, smoking.

\section{INTRODUCTION}

Oral squamous cell carcinoma (SCC) is the sixth most prevalent type of cancer and accounts for approximately $90 \%$ of all oral malignancies. Its incidence varies in different parts of the world, related to the action of specific risk factors (Salian et al., 2016). SCC development is strongly related to alcoholism and smoking. However, in the last decades, an increase in cases has been observed in women, as well as in young adults for whom other etiological factors such as genetic inheritance, eating habits and the presence of human papillomavirus (HPV) have been identified as causes (Quadri et al., 2015; Alves et al., 2017). It is worth noting that the main cause of lip SCC is related to excessive exposure to ultraviolet (UV) rays (Nagata et al., 2018).
According to information from the Global Cancer Observatory, the global estimate for new cases of oral cancer for 2018 was of 354,864 cases, 246,420 in males and 108,440 in females (World Health Organization, International Agency for Research on Cancer, 2019). In Brazil, an estimated incidence for 2018-2019 of 14,700 oral cancer cases has been reported, with 11,200 cases in men and 3,500 in women (Instituto Nacional do Câncer, 2017). It is known that lesion location is directly related to diagnosis and prognosis. Thus, lip SCC presents a better prognosis because it is easily identified and may be treated earlier (Souza-Cruz et al., 2014), while tongue SCC has been linked to worse prognosis (Nóbrega et al., 2018).

\footnotetext{
${ }^{1}$ Dentistry Undergraduate Student, Federal University of Rio Grande do Norte, Natal, RN, Brazil.

${ }^{2}$ Department of Oral Pathology, Federal University of Rio Grande do Norte, Natal, RN, Brazil.

${ }^{3}$ Department of Morphology, Federal University of Rio Grande do Norte, Natal, RN, Brazil.
}

Received: 2019-06-03 Accepted: 2021-02-01 


\section{MATERIAL AND METHOD}

The study protocol was approved by the Rio Grande do Norte Federal University (UFRN) Ethics Committee (Number 2.283.894). The inclusion criteria were all cases of lip and tongue SCC diagnosed between June 2001 and June 2018, selected among 15,300 oral lesions diagnosed at the UFRN Oral Pathology Service files. This service is one of the main oral and maxillofacial pathology referral centers in Brazil and the main center in the state of Rio Grande do Norte. Data regarding patient age, sex, duration, location, type of growth, staining, metastasis, etiologic agents and size were compiled from clinical data and biopsy records. The data were tabulated and analyzed by descriptive statistics using the IBM SPSS Statistics software (version 20.0; IBM Corp., Armonk, NY, USA).

\section{RESULTS}

A survey of cases diagnosed as lip and tongue SCC was carried out from June 2001 to June 2018, totaling 124 cases (Table I). Of this total, 76 where identified in males and 48 in females, with the fifth, sixth and seventh decades of life being the most affected. Exophytic growth was the most evidenced in $46.8 \%$ of the cases, followed by endophytic growth

Table I. Number of cases ( $\mathrm{n}$ ) and percentage (\%) in squamous cell carcinoma (SCC) of lip and tongue in the period of 2001 to 2018.

\begin{tabular}{|c|c|c|c|c|}
\hline \multirow{2}{*}{\multicolumn{2}{|c|}{ SCC Site }} & \multicolumn{3}{|c|}{ Total of Cases (n: 124) } \\
\hline & & $\mathrm{n}$ & $\begin{array}{l}\% \text { Total } \\
\text { of Cases }\end{array}$ & $\begin{array}{c}\% \text { Absolute } \\
\text { by Site }\end{array}$ \\
\hline Lip & & 34 & 27.4 & 100 \\
\hline \multicolumn{2}{|c|}{ Upper } & 1 & 0.8 & 3 \\
\hline \multicolumn{2}{|c|}{ Lower } & 33 & 26.6 & 97 \\
\hline \multirow[t]{2}{*}{ Tongue } & & 90 & 72.6 & 100 \\
\hline & Total & 124 & 100 & - \\
\hline
\end{tabular}

(25\%). This information was not present in $25 \%$ of the cases. In general, erythroleukoplastic staining was the most evident ( $30 \%)$ and the evolution time of the lesions at the time of diagnosis was of a maximum of 1 year after appearance in $67.7 \%$ of the cases. Metastasis was present in 15 cases (12.1\%), with smoking as most frequent etiologic factor in $11.3 \%$ of the cases. Lesion sizes ranged at about $2 \mathrm{~cm}$ in 40.3 $\%$ of the cases.
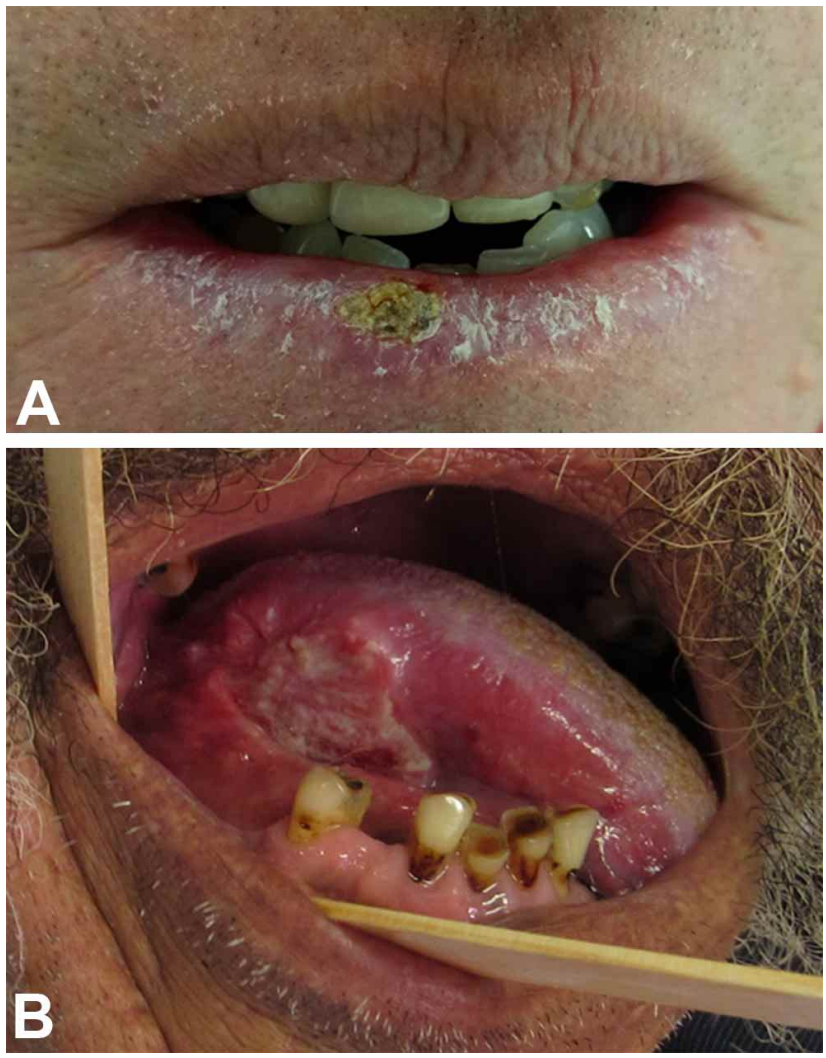

Fig. 1. Clinical evidence of lower lip squamous cell carcinoma (A) and oral tongue squamous cell carcinoma (B).

Lip SCC cases (Fig. 1A) corresponded to 27.4 $\%(n=34)$ of the total cases, with the lower lip being the most affected in $97 \%(n=33)$ (Table I), mostly in males (64.7\%) (Fig. 2A). The fifth and sixth decades

Table II. Number of cases ( $\mathrm{n}$ ) and percentage (\%) in squamous cell carcinoma (SCC) of lip and tongue in relation to the patient risk factors in the period between 2001 and 2018.

\begin{tabular}{|c|c|c|c|c|c|c|c|c|c|c|c|c|}
\hline \multirow[t]{3}{*}{ SCC Site } & \multicolumn{10}{|c|}{ Risk Factors } & \multicolumn{2}{|c|}{ Total of Cases } \\
\hline & \multicolumn{2}{|c|}{$\begin{array}{c}\text { No } \\
\text { Information }\end{array}$} & \multicolumn{2}{|c|}{ Smokers } & \multicolumn{2}{|c|}{$\begin{array}{l}\text { Chewing } \\
\text { Tobacco }\end{array}$} & \multicolumn{2}{|c|}{$\begin{array}{c}\text { Tobacco and } \\
\text { Alcohol }\end{array}$} & \multicolumn{2}{|c|}{ Sun Exposure } & & \\
\hline & $n$ & $\%$ & $n$ & $\%$ & $n$ & $\%$ & $n$ & $\%$ & $n$ & $\%$ & $n$ & $\%$ \\
\hline Lip & 28 & 82.3 & 2 & 5.8 & 1 & 3.1 & 0 & 0 & 3 & 8.8 & 34 & 27.4 \\
\hline Tongue & 71 & 78.9 & 12 & 13.3 & 0 & 0 & 7 & 7.8 & 0 & 0 & 90 & 72.6 \\
\hline Total & 99 & 79.8 & 14 & 11.3 & 1 & 0.9 & 7 & 5.6 & 3 & 2.4 & 124 & 100 \\
\hline
\end{tabular}


of life were the most affected lip SCC age groups, presenting nine $(26.5 \%)$ and eight $(23.5 \%)$ cases, respectively (Fig. 2B), with exophytic growth (Fig. 2C) being the most evidenced, in $38.8 \%$ of the cases ( $n=$ 11). The most observed staining in these lesions was leukoplastic (32.5\%) followed by erythroleukoplastic $(23.5 \%)$, while $26.5 \%$ of the case files did not contain this information (Fig. 2D). The time of lesion evolution (Fig. 3A) was of a maximum of 1 year after appearance in $61.8 \%$ of the cases, with evidence of metastasis (Fig. 3B) in $5.9 \%$ cases $(n=2)$. The etiological factor most related to lip SCC was sunlight exposure, in 8.8
$\%$ of cases, followed by regular smoking habits, at 5.8 $\%$ (Table II). The size of the lesions were mostly of up to $2 \mathrm{~cm}(41.2 \%)$, followed by larger lesions, ranging from $2 \mathrm{~cm}$ up to $4 \mathrm{~cm}$ in $20.6 \%$ of the cases, and 5.6 $\%$ presenting over $4 \mathrm{~cm}$ (Table III).

Of the 124 SCC cases, 90 (72.6\%) were located on the tongue (Fig. 1B; Table I), mostly observed in male patients $(60 \%)$ (Fig. $2 A)$. The fifth, sixth and seventh decades of life decades were the most frequent, at $27.7 \%, 20 \%$ and $17.7 \%$ respectively (Fig. 2B). Regarding type of growth, exophytic growth was

Table III. Number of cases (n) and percentage (\%) in squamous cell carcinoma (SCC) of lip and tongue related to lesion size in the period between 2001 and 2018.

\begin{tabular}{|c|c|c|c|c|c|c|c|c|c|c|}
\hline \multirow[t]{3}{*}{ SCC Site } & \multicolumn{8}{|c|}{ Lesion Size } & \multirow{2}{*}{\multicolumn{2}{|c|}{ Total of Cases }} \\
\hline & \multicolumn{2}{|c|}{ No Information } & \multicolumn{2}{|c|}{$\leq 2 \mathrm{~cm}$} & \multicolumn{2}{|c|}{$>2 \mathrm{~cm} \mathrm{a} \leq 4 \mathrm{~cm}$} & \multicolumn{2}{|c|}{$>4 \mathrm{~cm}$} & & \\
\hline & $n$ & $\%$ & $n$ & $\%$ & $n$ & $\%$ & $n$ & $\%$ & $n$ & $\%$ \\
\hline Lip & 11 & 32.3 & 14 & 41.2 & 7 & 20.6 & 2 & 5.9 & 34 & 27.4 \\
\hline Tongue & 21 & 23.3 & 36 & 40.1 & 20 & 22.2 & 13 & 14.4 & 90 & 72.6 \\
\hline Total & 32 & 25.8 & 50 & 40.3 & 27 & 21.8 & 15 & 12.1 & 124 & 100 \\
\hline
\end{tabular}
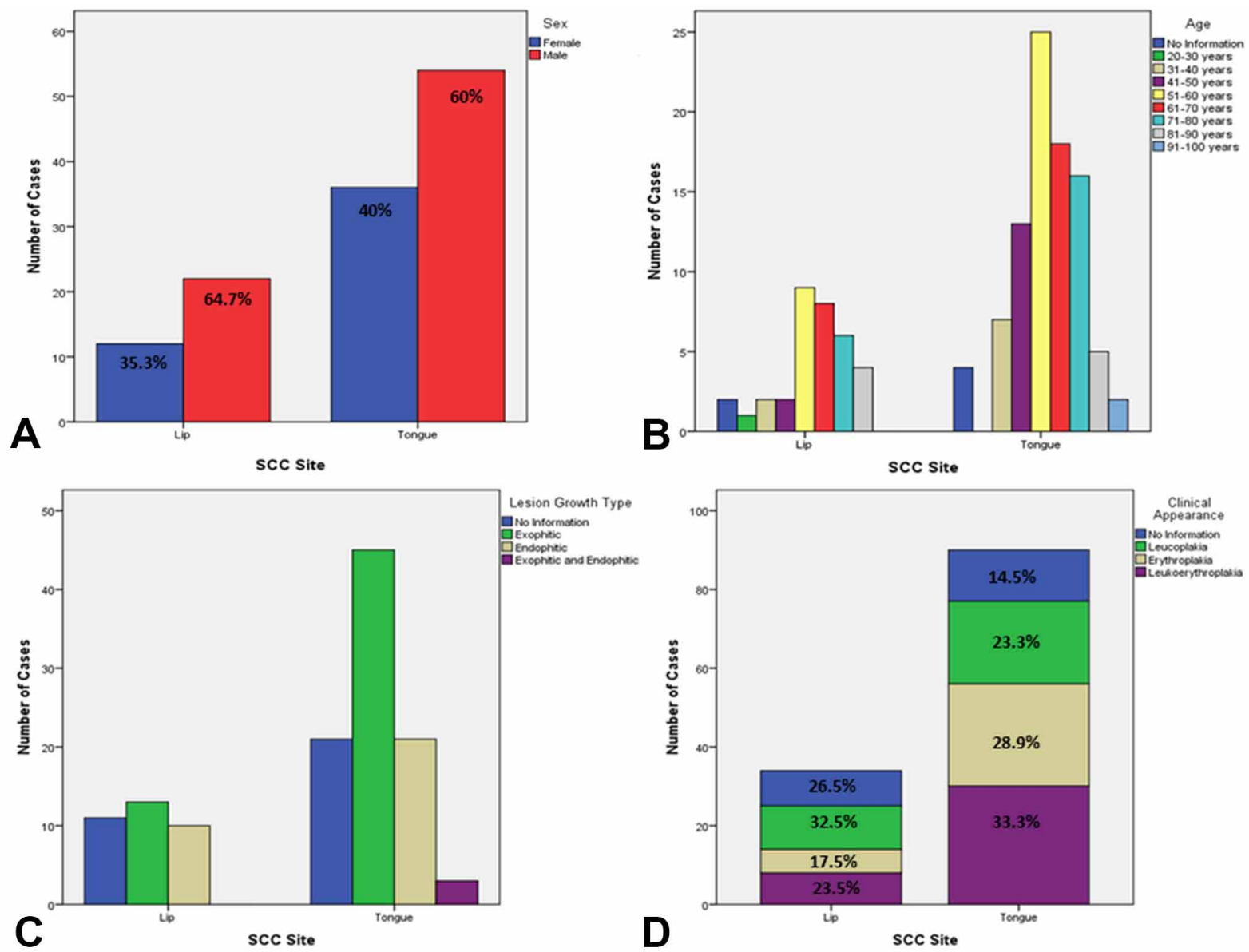

Fig. 2. Number of cases (n) and percentage (\%) related to sex (A); Number of cases (n) in relation to the age range of patients (B); Number of cases (n) related to lesion growth type (C); Number of cases $(n)$ and percentage (\%) of clinical appearance (D) in lip and tongue SCC patients between 2001 and 2018. 
present in $50 \%(n=45)$ of the cases, endophytic growth in $23.3 \%$ $(n=21)$, and exophytic/endophytic, in $3.4 \%(n=3)$. This information was not available in $23.3 \%(\mathrm{n}=$ 21) of the clinical records (Fig. 2C). The most evident tongue lesion staining was erythroleukoplastic (33.3 \%) followed by erythroplastic $(28.9 \%)$ and leukoplastic $(23.3 \%)$ (Fig. 2D). The evolution time of the lesion at the time of diagnosis (Fig. $3 \mathrm{~A}$ ) was at most 1 year in $70 \%$ (n $=63$ ) of the cases, and metastasis was evident in $14.4 \%(n=13)$ of the cases (Fig. 3B). Regular smo-

king habits was the most frequent etiologic agent in $13.3 \%(n=12)$ of the cases, followed by smoking combined with alcohol use, at $7.8 \%(n=7)$ (Table II). The size of the lesions was equal to or less than $2 \mathrm{~cm}$ in $40.1 \%$ of the cases, followed by lesions ranging from $2 \mathrm{~cm}$ up to $4 \mathrm{~cm}$ in $22.2 \%$ and over $4 \mathrm{~cm}$, in 14.4 $\%$ of the cases (Table III).

\section{DISCUSSION}

Males were the most affected by SCC, predominantly involving individuals from the fifth to the seventh decades of life, with smoking being the most frequent etiological factor. These findings corroborate previous studies, such as those carried out by Leite et al. (2018) and Khaleel et al. (2015). The link to smoking habits reflects the low efficiency of anti-smoking policies adopted in Brazil. One noteworthy fact is the high number of cases without information concerning the possible etiological agent, which may be due to the simple fact of incomplete filling of patient clinical records. Concerning the etiological agent, Koo et al. (2013) evidenced increasing oral SCC cases with no relation to traditional etiological factors such as tobacco or alcohol use, presenting a worse prognosis, something unexpected for these cases. The authors indicate a possible link to genetic alterations, conferring greater SCC aggressiveness and increased metastatic dissemination.

Regarding lesion size, lip SCC displayed a greater percentage of cases with a maximum size of 2 $\mathrm{cm}$, while tongue SCC cases presented sizes above 4 $\mathrm{cm}$ at a higher percentage rates when compared to lip SCC. In general, most analyzed SCC cases presented lesions smaller than $4 \mathrm{~cm}$. Similar findings were reported by Marocchio et al. (2010), who verified that oral SCC mostly reach a maximum of $3 \mathrm{~cm}$ compared to higher sizes. In view of these findings, it may be inferred that, as people obtain more access to health services, these lesions are most likely to be diagnosed at an early stage, leading to better prognosis.

A predominance of tongue SCC was noted compared to lip SCC, which was evidenced by Shenoi et al. (2012) and Souza-Cruz et al. The lower number of lip SCC is probably related to quicker treatment seeking, due to the favorable location of these lesions, where the patient easily identifies still incipient changes, sometimes pre-malignant, thus decreasing the appearance of malignant neoplasms in this region. It also important to note the shorter evolution time of lip SCC observed herein. On the other hand, many patients affected by tongue SCC take years to seek treatment, due to unfavorable lesion location. These lesions then become larger and present a higher degrees of invasiveness when the patient finally seeks treatment, confirmed by the more pronounced lesion sizes and higher percentage of tongue SCC metastasis observed herein.

Kerdpon et al. (2018) indicates that difficulty accessing health services, especially by the most deprived population, also leads to a delay in oral SCC diagnosis and consequently, more advanced development stages, with worse prognosis. It is clear that a broad, free and easily accessible population health system is inversely proportional to the identification of malignant lesions in more advanced stages, including oral SCC, resulting in better patient prognosis. In addition, public information policies concerning early cancer detection are also vital for this process. 
FREITAS, R. S. L. S.; MAIA, A. C.; RODRIGUES, R. R.; ROLIM, L. S. A.; SOUZA, L. B. \& ANDRADE SANTOS, P. P. Prevalence of lip and tongue squamous cell carcinoma (SCC) at a pathological anatomy service in Northeast Brazil. Int. J. Odontostomat., 15(2):409-414, 2021.

Lip SCC is mainly related to chronic exposure to solar UV radiation, especially UVB, with the lower lip affected in $80 \%$ of cases. In Brazil, lip SCC is a significant problem, as this is a tropical country with a high UV radiation incidence. In addition, a link to other factors is also noted, such as lifestyle, immunosuppression, alcohol and tobacco consumption, as well as genetic susceptibility, which may act synergistically (Borges et al., 2018). A predominance of lower lip involvement was observed in the present study, involving a higher number of male patients in the fifth and sixth decades of life, with related etiology plus sun exposure, followed by regular smoking habits or tobacco chewing. This information, however, was not available in a high percentage of the assessed clinical files.

A higher rate of tongue SCC cases was noted in the same age group compared to lip SCC, with the most important etiological factors being regular smoking habits and the combination of smoking and alcohol consumption. The oral tongue portion was the most affected compared to the pharyngeal portion. This etiopathogenesis was also highlighted by both Hernández-Guerrero et al. (2013) and Bodner et al. (2014), through the observation of classic risk factors like alcohol and tobacco consumption. The authors also noted a higher relationship of these factors in males. In the present study, the association between these risk factors and SCC was very strong and also verified predominantly in men.

Concerning age group at the time of diagnosis, Garzino-Demo et al. (2016) detected oral SCC presenting worse prognosis in patients younger than 40 , with a higher survival rate in patients older than 40. In the present study, the opposite was observed, considering that, in the 15 identified metastasis cases, thus presenting a worse prognosis, 14 were detected in patients over 40 , while only one case was observed in a patient younger than 40 .

The most evident clinical characteristics in lip and tongue SCC were a macroscopic growth pattern and a predominance of exophytic lesions in relation to endophytic lesions. This, however, is in contrast with the studies carried out by Pires et al. (2013) and Oliveira et al. (2015), who detected a predominance of endophytic lesions with clinical evidence of ulcerated lesions.

Regarding lesion staining, a greater number of erythroleukoplastic lesions was detected when assessing total cases. For lip SCC, a greater number of cases consisted in leukoplastic lesions, while tongue

SCC presented a higher percentage of erythroleukoplastic lesions. However, Leite et al. observed a greater number of leukoplastic lesions compared to leukoeritroplastic in oral SCC. In view of the findings reported herein, the evidence of a greater number of tongue leukoeritroplastic lesions reinforces the fact that oral SCC in this location often present a more aggressive behavior when compared to lip SCC, which should be a clinical alert for the attending clinician.

\section{CONCLUSIONS}

Although males are more affected by lip and tongue SCC, increasing rates of female involvement over the years, due to the adoption of deleterious habits such as smoking and alcoholism, have been observed. Tongue SCC was more linked to metastasis and clinical leukoeritroplastic evidence. This greater aggressiveness could be related to the unfavorable location of these lesions in relation to lip SCC, which may make it difficult to identify in early development stages.

FREITAS, R. S. L. S.; MAIA, A. C.; RODRIGUES, R. R.; ROLIM, L. S. A.; SOUZA, L. B. \& ANDRADE SANTOS, P. P. Prevalencia del carcinoma de células escamosas en labios y lengua (SCC) en un servicio de anatomía patológica en el Noreste Brasil. Int. J. Odontostomat., 15(2):409414, 2021.

RESUMEN: El objetivo de este trabajo fue rastrear un perfil epidemiológico y clínico de los casos de carcinoma oral de células escamosas (CCE) diagnosticados como CCE de labios y lengua entre junio de 2001 y 2018 en un servicio de anatomía patológica ubicado en el Noreste de Brasil. Los datos de edad, sexo, duración, ubicación, tipo de crecimiento, tinción, metástasis, agentes etiológicos y tamaño de la lesión se obtuvieron de los archivos clínicos de los pacientes y los informes histopatológicos. Se revisaron un total de 124 casos, siendo el CCE de lengua el más prevalente. Las características comunes de ambos CCE evaluados incluyeron mayor frecuencia en hombres, edad promedio de 60 años, evidencia mayoritariamente de lesiones exofíticas y tamaño máximo de $4 \mathrm{~cm}$, diagnosticado predominantemente después de un máximo de 1 año de aparición. En cuanto a los hallazgos divergentes, el CCE labial se presentó mayoritariamente en la porción inferior del labio, presentando un color predominantemente leucoplásico, con el hábito de fumar habitualmente y la luz solar identificados como los principales agentes etiológicos, sin una fuerte relación con las metástasis. Por otro lado, el CEC de la lengua presenta en su mayoría tinción predominantemente eritroleucoplásica, con una mayor relación con el tabaquismo asociado con el 
alcohol y con los hábitos habituales de tabaquismo. El mayor porcentaje de pacientes con metástasis presentó CCE de lengua. Aunque el CCE de labios y lengua muestra una preferencia en hombres, se ha observado una cantidad cada vez mayor prevalencia en mujeres a lo largo de los años, debido a la adopción de hábitos nocivos como el tabaquismo y el alcoholismo. El CCE de lengua presentó una mayor relación con la metástasis y la evidencia clínica leucoeritroplásica. Esta mayor agresividad podría estar relacionada con la ubicación desfavorable de estas lesiones en relación al CCE labial, dificultando en ocasiones su identificación en sus primeras etapas de desarrollo.

PALABRAS CLAVE: cáncer de labios, cáncer de lengua, cáncer de células escamosas, alcoholismo, de fumar.

\section{REFERENCES}

Alves, A. M.; Correa, M. B.; Silva, K. D.; Araújo, L. M. A.; Vasconcelos, A. C. U.; Gomes, A. P. N.; Etges, A. \& Tarquinio, S. B. C. Demographic and clinical profile of oral squamous cell carcinoma from a service-based population. Braz. Dent. J., 28(3):301-6, 2017.

Bodner, L.; Manor, E.; Friger, M. D. \& Wall, I. V. D. Oral squamous cell carcinoma in patients twenty years of age or younger Review and analysis of 186 reported cases. Oral Oncol., 50:849, 2014.

Borges, J. F. P.; Lanaro, N. D.; Bernardo, V. G.; Albano, R. M.; Dias, F.; de Faria, P. A. S.; Pinto, L. F. R. \& Lourenço, S. Q. C. Lower lip squamous cell carcinoma in patients with photosensitive disorders: Analysis of cases treated at the Brazilian National Cancer Institute (INCA) from 1999 to 2012. Med. Oral Patol. Oral Cir. Bucal, 23(1):e7-12, 2018.

Garzino-Demo, P.; Zavattero, E.; Franco, P.; Fasolis, M.; Tanteri, G.; Mettus, A.; Tosco, P.; Chiusa, L.; Airoldi, M.; Ostellino, O.; et al. Parameters and outcomes in 525 patients operated on for oral squamous cell carcinoma. J. Craniomaxillofac. Surg., 44:1414-21, 2016.

Hernández-Guerrero, J. C.; Jacinto-Alemán, L. F.; JiménezFarfán, M. D.; Macario-Hernández, A.; Hernández-Flores, F. \& Alcántara-Vázquez, A. Prevalence trends of oral squamous cell carcinoma. Mexico City's General Hospital experience. Med. Oral Patol. Oral Cir. Bucal, 18 (2):e306-11, 2013.

Instituto Nacional do Câncer (INCA). Estimativa 2018: incidência de câncer no Brasil / Instituto Nacional de Câncer José Alencar Gomes da Silva. Coordenação de Prevenção e Vigilância. Rio de Janeiro, INCA, Brasil, Ministério da Saúde, 2017. pp.3940.

Kerdpon, D.; Jantharapattana, K. \& Sriplung, H. Factors related to diagnostic delay of oral squamous cell carcinoma in southern Thailand: Revisited. Oral Dis., 24:347-54, 2018.

Khaleel, M. E.; Raza, A.; Ehsan, A.; Masood, R. \& Javed, M. Clinicopathological spectrum of oral squamous cell carcinoma at a public sector health facility. Biomedica, 31(1):21-6, 2015.

Koo, K.; Barrowman, R.; McCullough, M.; Iseli, T. \& Wiesenfeld, D. Non-smoking nondrinking elderly females: a clinically distinct subgroup of oral squamous cell carcinoma patients. Int. J. Oral Maxillofac. Surg., 42:929-33, 2013.
Leite, A. A.; Leonel, A. C. L. S.; Castro, J. F. L.; Carvalho, E. J. A.; Vargas, P. A.; Kowalski, L. P. \& Perez, D. E. C. Oral squamous cell carcinoma: a clinicopathological study on 194 cases in northeastern Brazil. A cross-sectional retrospective study. São Paulo Med. J., 136(2):165-9, 2018.

Marocchio, L. S.; Lima, J.; Sperandio, F. F.; Corrêa, L. \& de Sousa, S. O. Oral squamous cell carcinoma: an analysis of 1,564 cases showing advances in early detection. J. Oral Sci., 52(2):267-73, 2010.

Nagata, G.; Santana, T.; Queiroz, A.; Caramez, R. H. \& Trierveiler, M. Evaluation of epithelial dysplasia adjacent to lip squamous cell carcinoma indicates that the degree of dysplasia is not associated with the occurrence of invasive carcinoma in this site. J. Cutan. Pathol., 45(9):647-51, 2018.

Nóbrega, T. D.; Queiroz, S. I. M. L.; Santos, E. M.; Costa, A. L. L.; Pereira-Pinto, L. \& de Souza, L. B. Clinicopathological evaluation and survival of patients with squamous cell carcinoma of the tongue. Med. Oral Patol. Oral Cir. Bucal, 23(5):e579-87, 2018.

Oliveira, M. L. C.; Wagner, V. P.; Sant'Ana Filho, M.; Carrard, V. C.; Hugo, F. N. \& Martins, M. D. A 10-year analysis of the oral squamous cell carcinoma profile in patients from public health centers in Uruguay. Braz. Oral Res., 29(1):1-8, 2015.

Pires, F. R.; Ramos, A. B.; Oliveira, J. B. C.; Tavares, A. S.; Luz, P. S. R. \& Santos, T. C. R. B. Oral squamous cell carcinoma: clinicopathological features from 346 cases from a single Ora Pathology service during an 8-year period. J. Appl. Oral Sci., 21(5):460-7, 2013.

Quadri, M. F. A.; Alharbi, F.; Bajonaid, A. M. S.; Moafa, I. H. Y.; Sharwani, A. A. \& Alamir, A. H. A. Oral squamous cell carcinoma and associated risk factors in Jazan, Saudi Arabia: a hospital based case control study. Asian Pac. J. Cancer Prev., 16(10):4335-8, 2015.

Salian, V.; Dinakar, C., Shetty, P. \& Ajila, V. Etiological trends in oral squamous cell carcinoma: a retrospective institutional study. Cancer Transl. Med., 2(2):33-6, 2016.

Shenoi, R.; Devrukhkar, V.; Chaudhuri Sharma, B. K.; Sapre, S. B. \& Chikhale, A. Demographic and clinical profile of oral squamous cell carcinoma patients: A retrospective study. Indian J. Cancer, 49:21-6, 2012.

Souza-Cruz, A. C.; Franzolin, S. O. B.; Pereira, A. A. C.; Hanneman, J. A. C.; Beijo, L. A. \& Souza Cruz, J. R. Oral squamous cell carcinoma: survival, recurrence and death. Acta Scientiarum, 36(2):273-9, 2014

World Health Organization, International Agency for Research on Cancer. Cancer Today. Estimated Number of New Cases of Lip and Oral Cancer in 2018, Worldwide, Females, All Ages, 2019. Geneva, World Health Organization, 2019. Available from: https://gco.iarc.fr/

\section{Corresponding author:}

Pedro Paulo de Andrade Santos, DDS, PhD

Universidade Federal do Rio Grande do Norte (UFRN)

Centro de Biociências - Departamento de Morfologia

Campus Universitário Lagoa Nova - Natal/RN

CEP: $59072-970$

BRASIL

E-mail: ppdasantos@gmail.com 